\title{
Panes, Cereales, Arroz y Pastas Alimenticias: El grupo de los productos a base de granos ${ }^{1}$
}

Glenda L. Warren ${ }^{2}$

Escoja 6-11 porciones todos los días. Escoja granos enteros frecuentemente.

\section{¿Qué es una porción?}

- 1 rebanada de pan

- 1 onza de cereal listo para comer

- $1 / 2$ taza de cereal, arroz o pasta cocida

- $\quad 1 / 2$ pan de hamburguesa, mollete inglés o un mollete pequeño

- 1 panecillo

- 3-4 galletas de soda pequeñas ó 2 grandes

Usted necesita por lo menos 6 porciones de productos a base de granos en su dieta 3 a 5 de esas porciones deben ser productos de grano íntegro así que escoja granos íntegros frecuentemente.

- Los panes, cereales, arroz y pasta alimenticias forman la base de la Pirámide de los Alimentos.
- Ellos proveen almidón (carbohidratos complejos), algunas vitaminas B, minerales y proteína a una dieta balanceada. En adición a los nutrientes que se encuentran en productos enriquecidos, los productos de granos enteros también proveen ácido fólico, magnesio y fósforo.

- La fibra dietaría provee volumen a la dieta y ayuda en el tránsito de los desperdicios a través del sistema intestinal ayudando a prevenir y a controlar el estreñimiento y otras condiciones que pueden irritar los intestinos. Algunos tipos de fibra ayudan a prevenir estreñimiento y otros tipos pueden ayudar a disminuir el nivel de colesterol en la sangre.

1. This document is FCS1054-Span, one of a series of the Department of Family, Youth and Community Sciences, Florida Cooperative Extension Service, Institute of Food and Agricultural Sciences, University of Florida. Publication date: May 2003. First published: September 1997. Reviewed by: Jennifer Hillan, MSH, RD, LD/N, Family, Youth \& Community Sciences, University of Florida, Gainesville, FL 32611. Please visit the EDIS Web site at http://edis.ifas.ufl.edu

2. Glenda L. Warren, M.S., R.D., CFCS, associate professor, Extension Nutritionist-EFNEP, Family, Youth and Community Sciences, Cooperative Extension Service, Institute of Food and Agricultural Sciences, University of Florida, Gainesville, 32611.

The Institute of Food and Agricultural Sciences is an equal opportunity/affirmative action employer authorized to provide research, educational information and other services only to individuals and institutions that function without regard to race, color, sex, age, handicap, or national origin. For information on obtaining other extension publications, contact your county Cooperative Extension Service office. Florida Cooperative Extension Service / Institute of Food and Agricultural Sciences / University of Florida / Christine Taylor Waddill, Dean 


\section{Ideas sobre como preparar Panes, Cereales, Arroz y Pastas Alimenticias}

- Cocine las pastas y el arroz sin sal ni grasa. Puede usar caldo de carne sin sal o jugo de tomate para darie sabor.

- Pruebe las pastas de grano integro que están disponibles en los colmados.

- Pruebe el arroz integral; tiene más sabor y más fibra.

- Prepare una ensalada de pasta para la comida o el alrnuerzo. Es fácil de preparar y se puede dar buen uso a los sobrantes. No use mucha mayonesa, o use la mayonesa baja en grasa o aderezo.

- Use harina de trigo integral. Substituya una porción de harina de trigo regular por una porción de harina de trigo integral en sus recetas.

\section{La fibra es necesaria para una dieta saludable}

- La fibra ayuda en las digestión de alimentos.

- La fibra puede reducir el colesterol y puede reducir el riesgo de condiciones cardíacas.

- La fibra ayuda en la protección contra ciertos tipos de cáncer.

- La fibra es importante para reducir los síntomas de estreñimiento crónico, de problemas con divertículos y hemorroides.
- La fibra se encuentra solamente en alimentos de origen vegetal como los panes y cereales de granos íntegros, frijoles y guisantes y vegetales $\mathrm{y}$ frutas.

- Debido a que existen diferentes tipos de fibra en los alimentos debe escoger una variedad de alimentos diariamente.

- Algunos de los beneficios a la salud asociados con una dieta alta en fibra pueden deberse a otros compuestos presentes en los alimentos y no exclusivamente a la fibra.

- Es mejor obtener la fibra de alimentos que de suplementos.

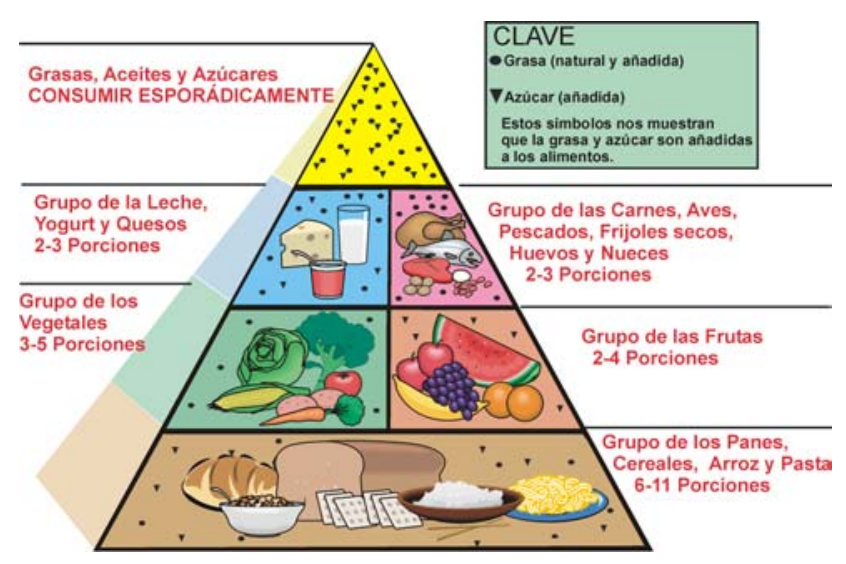

Consuma bastante fibra dietaría y tome bastante agua.

\footnotetext{
This publication is supported with funding from the Expanded Food and Nutrition Education Program, USDA's Food Stamp Program, Florida Department of Children and Families, and University of Florida Cooperative Extension Service, in collaboration with state, county, and local agencies. The Food Stamp Program gives nutrition assistance to people with low income. It can help you buy nutritious foods for a better diet. To find out more, call 1-800-342-9274 (toll-free).
} 